\title{
American Listening Foreign Languages Evaluation for Development study of BIPA Listening Evaluation
}

\author{
Ida Widia', Rosita Rahma ${ }^{2}$, Mar'atushshalihah $^{3}$, Encep Kusumah ${ }^{4}$ \\ Indonesia University of Education \\ 1idawidia@upi.edu, 2rositarahma@upi.edu, ${ }^{3}$ maratushalihah@student.upi.edu, \\ 4encepkusumah@upi.edu
}

\begin{abstract}
The need for BIPA evaluation models, especially listening, which conforms to foreign language evaluation standards is needed to measure the abilities and skills of BIPA learners. Until now, there has not been found a comprehensive BIPA evaluation model. Although in Indonesia there is UKBI, UKBI has not been able to measure the language proficiency of foreign speakers holistically. UKBI is still used to measure the proficiency of Indonesian speakers and foreign speakers simultaneously. This has become one of the problems being faced. One solution to overcome these problems is to develop an evaluation tool to measure the ability and skills of BIPA learners, especially in listening skills. Therefore, it is very much needed an analytical study related to the listening evaluation model for foreign speakers used in the United States as a reference for the development of the BIPA listening measure. The purpose of this study is to describe the results of the analysis of foreign language evaluation tools in the American region as a base in developing listening evaluation model of BIPA. The data source of this research is a foreign language evaluation tool which is used as a tool to measure the proficiency of non-English foreign speakers. Data collection in this study uses documentation techniques. The data that will be produced in this study are qualitative data in the form of listening content evaluation standards used in the United States.
\end{abstract}

Keywords: listening evaluation, BIPA, foreign language

\section{PENDAHULUAN}

Munculnya Peraturan Menteri Tenaga Kerja (Permenaker) Nomor 12 Tahun 2013 tentang persyaratan tenaga kerja asing menjadi salah satu faktor pentingnya pengujian kemahiran berbahasa Indonesia bagi pekerja asing. Peraturan agar tenaga kerja asing harus berbahasa Indonesia telah diberlakukan. Menteri Pendidikan Nasional telah mengukuhkan Uji Kemahiran Bahasa Indonesia (UKBI) sebagai barometer nasional dalam menentukan kemampuan berbahasa Indonesia masyarakat [1]. UKBI merupakan alat ukur untuk menentukan tingkat kemahiran berbahasa Indonesia seseorang. Alat ukur ini tidak sepopular TOEFL (Test of English as a Foreign Language) yang bertujuan untuk menguji kemampuan berbahasa Inggris. Perbedaan UKBI dan TOEFL dapat dilihat dari partisipannya. TOEFL digunakan untuk mengukur kemampuan berbahasa Inggris bagi pembelajar asing (pengguna bahasa Inggris sebagai bahasa kedua), sedangkan UKBI digunakan baik bagi penutur sejati maupun penutur asing, dengan kata lain UKBI mengukur kemahiran berbahasa Indonesia bagi 
semua penutur baik warga negara Indonesia maupun warga negara asing dalam bentuk lisan dan tulis [1]. UKBI dikembangkan berdasarkan empat keterampilan berbahasa Indonesia, yakni keterampilan menyimak, berbicara, membaca, dan menulis.

Terdapat dua jenis tes untuk mengukur kemampuan berbahasa asing yang berada di wilayah Amerika yakni TOEFL dan TOEIC. TOEFL merupakan salah satu jenis tes standar untuk menguji kemampuan berbahasa Inggris seseorang pemelajar asing sebagai syarat mutlak untuk melanjutkan pendidikan ke jenjang yang lebih tinggi[2]. Sama halnya seperti UKBI, TOEFL juga dikembangkan berdasarkan keterampilan berbahasa, hanya saja TOEFL terdiri dari keterampilan menyimak, membaca, menulis, dan struktur kebahasaan. Meskipun tidak mengandung bagian keterampilan berbicara, banyak guru bahasa Inggris berasumsi bahwa semakin tinggi skor TOEFL, semakin besar kemungkinan peserta tes dapat berkomunikasi bahasa Inggris dalam konteks akademik[3]. Di Amerika Utara TOEFL dirancang untuk mengevaluasi kemampuan berbahasa Inggris bagi orang-orang yang bahasa ibunya bukan bahasa Inggris[4]. TOEFL terdiri atas beberapa jenis tes, yaitu IBT (Internet Based Test), CBT (Computer Based Test), dan PBT (Paper Based Test). Hasil dari penutur asing Bahasa Inggris yang mengikuti tes TOEFL akan diberikan lisensi yang terdaftar dari Educational Testing Service (ETS), lembaga tersebut dikelola diseluruh dunia[2].

Selain TOEFL, terdapat alat ukur lain untuk mengukur kemahiran berbahasa asing yaitu TOEIC (Test of English for International Communication). TOEIC terdiri dari 200 pertanyaan pilihan ganda untuk mengukur kemampuan bahasa Inggris sehari-hari dan mencakup dua keterampilan bahasa yaitu mendengarkan (menyimak) dan membaca[5]. Perbedaan TOEFL dan TOEIC terletak pada tingkat kesulitan. TOEIC relatif lebih mudah dibandingkan dengan TOEFL karena TOEIC hanya mengukur kemahiran berbahasa Inggris pada tahap percakapan sehari-hari.

Mengacu kepada tahap pembelajaran bahasa, keterampilan menyimak adalah keterampilan yang pertama kali digali. Selanjutnya keterampilan berbicara, keterampilan membaca, dan keterampilan menulis. Keterampilan menyimak terbagi menjadi 3 bagian: keterampilan mempersepsi, keterampilan menganalisis, dan keterampilan menyintesis. Ketiga bagian tersebut harus tergambar dalam pengujian keterampilan berbahasa khususnya menyimak. Keterampilan menyimak itu penting karena kemahiran dalam menyimak dan mendengarkan berkontribusi paling besar pada pembelajaran. Sehubungan dengan itu, dari empat komunikasi verbal yang digunakan seseorang dalam kehidupan sehari-hari, seseorang lebih sering menggunakan keterampilan menyimak dan mendengarkan[6].

Saat ini, kebutuhan model evaluasi BIPA, khususnya menyimak, yang sesuai dengan standar evaluasi bahasa asing sangat diperlukan untuk mengukur kemampuan dan keterampilan pembelajar BIPA. [1] Evaluasi menyimak dapat dibuat dengan menyertakan kunci jawaban. Skor jawaban pilihan ganda lebih kecil daripada skor jawaban esai. Sementara skor jawaban esai bisa saja berbeda-beda antara satu jawaban dengan jawaban lainnya. Selain itu, evaluasi menyimak juga dapat dilakukan melalui aspek psikolinguistik, karena aspek psikolinguistik dalam proses pembelajaran dapat diamati. Guru dapat mengamati perilaku siswa di dalam kelas. Contoh perilaku yang berkaitan dengan psikolingiustik di antaranya percaya diri, kerja sama, disiplin, menghargai pendapat, dan motivasi. Aspek ini bisa pula diamati atau diukur. Dengan begitu aspek ini dapat dihubungkan dengan prestasi siswa.

Hingga saat ini belum ditemukan model alat evaluasi BIPA yang komprehensif. Walaupun di Indonesia terdapat UKBI, akan tetapi UKBI belum dapat mengukur kemahiran berbahasa penutur asing secara holistik. UKBI pun masih digunakan untuk mengukur kemahiran berbahasa penutur bahasa Indonesia dan penutur asing secara bersamaan. Hal tersebut menjadi salah satu permasalahan yang sedang dihadapi. Salah satu cara untuk 
mengatasi permasalahan tersebut yakni mengembangkan sebuat alat evaluasi untuk mengukur kemampuan dan keterampilan pembelajar BIPA khususnya pada keterampilan menyimak. Oleh karena itu, sangat dibutuhkan kajian analisis terkait dengan model alat evaluasi menyimak untuk penutur asing yang digunakan di wilayah Amerika sebagai acuan untuk pengembangan alat ukur menyimak BIPA. Berdasarkan uraian latar belakang tersebut, didapatkan sebuah rumusan masalah yakni bagaimana hasil analisis alat evaluasi menyimak bahasa asing di wilayah Amerika sebagai landasan pengembangan model alat evaluasi BIPA? Tujuan dari penelitian ini adalah mendeskripsikan hasil analisis alat evaluasi menyimak bahasa asing wilayah Amerika sebagai landasan pengembangan model alat evaluasi BIPA.

\section{METODE PENELITIAN}

Penelitian ini menggunakan metode deskriptif kualitatif. Data pada penelitian ini akan dianalisis melalui beberapa tahapan penelitian berikut: (1) melakukan analisis kebutuhan alat evaluasi menyimak BIPA; (2) pemilihan dan klasifikasi jenis-jenis alat evaluasi bahasa asing yang digunakan di wilayah Amerika; (3) melakukan analisis standar isi pada alat evaluasi bahasa asing yang digunakan di wilayah Amerika. Sumber data penelitian ini adalah alat evaluasi bahasa Inggris sebagai bahasa kedua yang digunakan sebagai alat untuk mengukur kemahiran penutur asing non-bahasa Inggris. Pengumpulan data pada penelitian ini menggunakan teknik dokumentasi. Data yang akan dihasilkan dalam penelitian ini adalah data kualitatif berupa standar isi alat evaluasi menyimak yang digunakan di wilayah Amerika. Pengolahan data dalam penelitian ini akan diolah dengan menggunakan teknik pengolahan data kualitatif yakni melalui tahapan (1) inventarisasi data, (2) klasifikasi data, (3) analisis data, (4) penafsiran data, dan (5) pembuatan simpulan.

\section{HASIL DAN PEMBAHASAN}

Jenis tes yang digunakan untuk mengukur kemahiran berbahasa Inggris di wilayah Amerika adalah TOEFL dan TOEIC. Tes TOEFL umumnya digunakan sebagai tes penempatan di suatu Universitas, terutama dalam Program Bahasa Inggris. Ada dua jenis tes TOEFL, yaitu tes TOEFL berbasis komputer dan tes TOEFL berbasis kertas. Kedua jenis tes TOEFL tersebut terdiri dari empat bagian yakni bagian mendengarkan (menyimak), bagian struktur bahasa, bagian membaca, dan bagian menulis[7]. Sedangkan tes TOEIC merupakan tes bahasa Inggris berbentuk pilihan ganda untuk penutur asing yang bahasa ibunya bukan bahasa Inggris. TOEIC terdiri dari dua bagian yakni keterampilan menyimak dan keterampilan membaca. Perbedaan TOEFL dan TOEIC terletak pada tingkat kesulitan. TOEIC relatif lebih mudah dibandingkan dengan TOEFL karena TOEIC hanya mengukur kemahiran berbahasa Inggris pada tahap percakapan sehari-hari [16].

TOEFL memiliki dua tingkatan yakni level 1 dan level 2. Perbedaannya terletak pada jumlah pertanyaan dan alokasi waktu. Pada level 1, terdapat 50 soal untuk bagian menyimak, 40 soal untuk bagian struktur dan menulis, 50 soal untuk bagian membaca. Total keseluruhan soal yaitu 140 soal dengan alokasi waktu 115 menit, 35 menit untuk bagian menyimak, 25 menit untuk bagian struktur dan menulis, serta 55 menit untuk bagian membaca. Rentang skor yang didapatkan untuk level 1 adalah 31-68 untuk bagian menyimak, struktur, dan menulis, serta rentang 31-67 untuk bagian membaca. Total keseluruhan rentang skor untuk level 1 adalah 310-677. Sedangkan untuk level 2, terdapat 30 soal untuk bagian menyimak, 25 soal untuk bagian struktur dan menulis, dan 40 soal untuk bagian membaca. Total keseluruhan soal yaitu 95 soal dengan alokasi waktu waktu 22 menit untuk bagian menyimak, 17 menit untuk 
bagian struktur dan menulis, dan 31 menit untuk bagian membaca. Total alokasi waltu pada level 2 adalah 70 menit dengan rentang skor 20-50 untuk tiap-tiap bagian. Total rentang skor pada level 2 adalah 200-500[8].

Pada bagian menyimak, ada beberapa hal yang harus dilakukan yaitu mengidentifikasi makna dari sebuah percakapan, pemahaman struktur dari sebuah dialog atau monolog, pemahaman makna dalam sebuah konteks, pemahaman topik dalam sebuah pernyataan, pemahaman yang detail dari sebuah percakapan, dan penentuan kesimpulan sebuah konteks. Pada bagian struktur dan menulis, hal yang harus dilakukan adalah mengidentifikasi kata benta pada sebuah konteks tertentu, mengidentifikasi sebuah artikel, mengidentifikasi kata ganti dan kata sifat, mengidentifikasi kata kerja, subjek, atau kata ganti orang, mengidentifikasi frasa dan klausa, serta mengidentifikasi struktur paralel. Pada bagian membaca, hal yang harus dilakukan adalah mengidentifikasi ide pokok, memahami kosa kata, serta mengidentifikasi ilustrasi yang sesuai dengan konteks[9].

Pada umumnya, TOEFL dan TOEIC adalah tes yang sama-sama mengukur kemahiran berbahasa Inggris bagi penutur asing yang bahasa ibunya bukan bahasa Inggris. Perbedaannya terletak pada tingkat kesulitannya. TOEIC relatif lebih mudah karena tes yang dilakukan adalah untuk mengukur keterampilan berbahasa Inggris pada konteks komunikasi sehari-hari. Akan tetapi TOEIC tetap memiliki ketentuan tes tersendiri. Berbeda dengan TOEFL, TOEIC terdiri dari dua bagian yaitu bagian menyimak dan bagian membaca. TOEIC juga memiliki dua versi yang berbeda, yakni versi dulu dan versi terbaru. Perbedaannya terletak dari jenis soal yang diberikan. Pada bagian menyimak TOEIC versi dulu, disediakan 100 soal dengan alokasi waktu 45 menit terdiri dari 20 soal identifikasi gambar atau foto sedangkan untuk versi terbaru terdiri dari 10 soal identifikasi gambar atau foto. Jenis soal merespon pertanyaan terdiri dari 30 soal baik versi lama maupun versi baru. Pada jenis soal percakapan, pada versi lama terdapat 30 soal 30 percakapan pendek, setiap satu soal terdiri dari satu percakapan pendek, sedangkan untuk versi baru terdapat 30 soal untuk 10 percakapan, setiap percakapan terdiri dari tiga soal. Pada jenis soal monolog, pada versi lama terdapat 20 soal terkait monolog singkat, sedangkan pada versi baru terdapat 30 pertanyaan untuk 10 monolog, setiap monolog terdiri dari 3 soal.

Pada bagian membaca, diberikan alokasi waktu 75 menit untuk 100 soal yang terdiri dari 40 soal tentang kalimat tidak lengkap baik versi lama maupun versi baru. Pada TOEIC versi lama terdapat 20 soal tentang kesalahan-kesalahan penyataan dalam teks, sedangkan pada versi baru terdapat 12 soal tentang penyelesaian teks rumpang. Pada TOEIC versi lama terdapat 40 soal tentang menjawab pertanyaan berdasarkan teks, grafik, tabel, atau gambar, sedangkan pada versi yang baru terdapat 48 soal tentang menjawab pertanyaan berdasakan teks, grafik, tabel, atau gambar (28 soal dengan satu teks, 20 soal untuk teks ganda)[10].

ETS (Educational Testing Service) menetapkan kisaran skor TOEIC adalah 10-990 terdiri dari enam level: 1) Level 0/0 + Novice (skor 10-250), 2) Level 1 Elementary (skor 255400), 3) Level 1+ Intermediate (skor 405-600), 4) Tingkat 2 Basic Working Proficiency (skor 605-780), 5) Tingkat 2+ Advance Working Proficiency (skor 785-900), dan 6) Tingkat 3/3+ General Professional Proficiency (skor 905-990)[5].

\section{SIMPULAN}

Secara umum, dibutuhkan penyusunan kembali standar kompetensi lulusan BIPA sesuai dengan tingkat kemampuan peserta tes. Dalam pembelajaran BIPA, perlu diketahui bahasa Indonesia merupakan bahasa asing bagi pemelajar. Hal tersebut menunjukkan bahwa pemelajar BIPA menjadikan pembelajaran bahasa Indonesia sebagai pembelajaran bahasa 
kedua atau bahasa asing. Setiap pemelajar BIPA memiliki bahasa ibu atau bahasa pertama yang dikuasainya. Struktur bahasa pertama tersebut tentu akan berpengaruh terhadap proses belajar bahasa Indonesia. Oleh karena itu, tidak bisa disamakan antara pemelajar asing dan pemelajar asli Indonesia. Alat ukur yang digunakan pun seharusnya berbeda. Jika UKBI digunakan untuk mengukur kemampuan berbahasa Indonesia bagi penutur asli bahasa Indonesia, maka harus terdapat pula alat ukur yang sesuai dengan tingkat kemampuan pembelajar BIPA. TOEFL dan TOEIC dapat dijadikan acuan untuk mengembangkan alat ukur kemahiran berbahasa asing karena telah berstandar internasional.

\section{REFERENCES}

[1] P. D. Iswara, "Pengembangan Materi Ajar dan Evaluasi pada Keterampilan Mendengarkan dan Membaca,” Mimbar Sekolah Dasar, vol. 3 (1), pp. 89-97, 2006.

[2] H. G. Tarigan, Membaca Sebagai Suatu Keterampilan Berbahasa, Bandung: Angkasa Bandung, 2008.

[3] Sugiono, Metode Penelitian Kuantitatif Kualitatif dan R\&D, Bandung: Alfabeta, 2012.

[4] G. Razati och R. Ruhimat, "Pengaruh Sales Promotion Terhadap Keputusan Menggunakan Kartu Kredit BNI,” Jurnal Pendidikan Manajemen Bisnis, pp. 1-15, 28.

[5] R. Rahma, "Praktik Pembelajaran BIPA Tingkat Dasar di Hungaria Melalui Permainan Congklak," i SETALI, Bandung, 2016.

[6] M. M. Mussaif, "Keanekaragaman Budaya Menjadi Basis Pembelajaran BIPA," Keanekaragaman Budaya Menjadi Basis Pembelajaran BIPA, vol. 12, p. 169, 2017.

[7] Moh. Muzakka, "Keanekaragaman Budaya Menjadi Basis Pembelajaran BIPA," NUSA, vol. 12, pp. 170-171, 2017.

[8] K. Kurniawan, Belajar dan Pembelajaran Bahasa Indonesia (Panduan untuk Pendidik), Bandung: CV Bangkit Citra Persada, 2012.

[9] E. Kosasih, Dasar-dasar Keterampilan Bersastra, Bandung: Yrama Widya, 2012.

[10] E. Iswary, "Strategi Pembelajaran Bahasa Indonesia Secara Terpadu," i International Conference at Hankuk University of Foreign Studies (HUFS), Seoul, 2012.

[11] Hertiki, "PENGAJARAN DAN PEMBELAJARAN BIPA DI PERGURUAN TINGGI POLANDIA,” Jurnal Pendidikan Bahasa dan Sastra Indonesia, vol. 6, p. 1, 2017.

[12] S. Endraswara, Metodologi Penelitian Folklore Konsep, Teori, dan Aplikasi, Yogyakarta: PT Buku Kita, 2009.

[13] Rebecca Isbell, Joseph Sobol, Liane Lindauer, and April Laurence, "The Effects of Storytelling and Story Reading on the Oral Language Complexity and Story Comprehension of Young Children," Early Childhood Education Journal, vol. 32, p. 158, 2004.

[14] Scumacher dan McMillan, Research in Education, New York: Longman, 2001.

[15] Aan Komariah dan Djam'an Satori, Metode Penelitian Kualitatif, Bandung: Alfabeta, 2011.

[16] K. Saddhono, A. Hasibuan, and M. I. Bakhtiar, "Facebook as A Learning Media in TISOL (Teaching Indonesian to Speakers of Other Languages) Learning to Support The Independency of Foreign Students in Indonesia," in Journal of Physics: Conference 
Series, 2019, vol. 1254, no. 1, p. 12061. 